\title{
The Use of Sodium Silicate as a Corrosion Inhibitor in a Saline Drilling Fluid: A Nonaggressive Option to the Environment
}

\author{
Fernando B. Mainier*, Anne A. M. Figueiredo, Alan Eduardo R. de Freitas, \\ André Armando M. de Alencar Junior
}

Escola de Engenharia, Universidade Federal Fluminense, Niterói, Brazil

Email: ^fmainier@uol.com.br

How to cite this paper: Mainier, F.B., Figueiredo, A.A.M., de Freitas, A.E.R. and de Alencar Junior, A.A.M. (2016) The Use of Sodium Silicate as a Corrosion Inhibitor in a Saline Drilling Fluid: A Nonaggressive Option to the Environment. Journal of Environmental Protection, 7, 2025-2035. http://dx.doi.org/10.4236/jep.2016.713157

Received: November 8, 2016

Accepted: December 13, 2016

Published: December 16, 2016

Copyright $\odot 2016$ by authors and Scientific Research Publishing Inc. This work is licensed under the Creative Commons Attribution International License (CC BY 4.0).

http://creativecommons.org/licenses/by/4.0/

\begin{abstract}
The function of a corrosion inhibitor in drilling mud compositions is the corrosion protection of the equipment involved in drilling operations. Many compositions involve environmentally several products such as fatty amines of high molecular weight, polyoxylated amines, amides, imidazolines, nitrogen heterocyclic products, etc. The potential advantages of the use of silicates are the effective protection of carbon steel, especially in aerated saline fluids, low costs and non-aggressive behavior to environment. Gravimetric and electrochemical tests were carried out using an aerated solution of $3.5 \% \mathrm{NaCl}$ and the addition of sodium silicate $\left(\mathrm{Na}_{2} \mathrm{SiO}_{3} \cdot 9 \mathrm{H}_{2} \mathrm{O}\right)$ as a corrosion inhibitor at concentrations of 250 to $2000 \mathrm{mg} / \mathrm{L}$. The efficiencies of the corrosion protection of carbon steel using silicate concentrations greater than 1250 $\mathrm{mg} / \mathrm{L}$ were greater than $92 \%$.
\end{abstract}

\section{Keywords}

Sodium Silicate, Corrosion Inhibitor, Environment, Aerated Saline Fluid, Carbon Steel

\section{Introduction}

The direct and indirect costs of a failure or fracture in oil well drilling are relatively high, especially when they are associated with the time lost during the recovery process, the placement of a new drill and/or the loss of the oil well [1] [2].

To minimize these costs, facts must be established in the following programs:

- A specific inspection of the drill column and a study of the variables associated with the drilling techniques and the history of the column used, especially taking into 
consideration some parameters such as aggressive media knowledge of penetration, contamination (high salinity, oxygen, carbon dioxide, hydrogen sulphide), the thickness limits of the drill pipe, the evaluation of internal and external pitting (Figure 1), rotation speed, vibration, bending and coaxial loads;

- An evaluation of specific additives (corrosion inhibitor) to eliminate or reduce the corrosiveness of drilling fluids that are compatible with the environment.

According to Fink [1], drilling muds are mixtures of natural and synthetic chemical compounds used to cool and lubricate the drill string and bit, to remove rock bit cuttings from the bottom of the hole and carry them to the surface, to overcome the fluid pressure of the formation, to avoid damage of the producing formation and to prevent drill pipe corrosion.

There is no doubt that such points are vital in studies of the faced corrosion problems when drilling oil wells and all items justify a careful evaluation.

The function of corrosion inhibitors in saline fluids is to inhibit and/or neutralize the aggressive contaminants present in and/or forming on the surface of carbon steel. They provide a resistant and adherent film that prevents the development of corrosive reactions. The aggressiveness of saline fluids can be increased by incorporating contaminants such as dissolved oxygen $\left(\mathrm{O}_{2}\right)$, carbon dioxide $\left(\mathrm{CO}_{2}\right)$ and hydrogen sulphide $\left(\mathrm{H}_{2} \mathrm{~S}\right)$.

However, the objective of this article is to show, through laboratory experiments, that corrosion inhibitors based on sodium silicate can be added to aerated saline fluids with an excellent performance for the corrosion protection of carbon steel. In addition, the growing concern for environmental conservation in terms of chemicals is pointed out in this way.

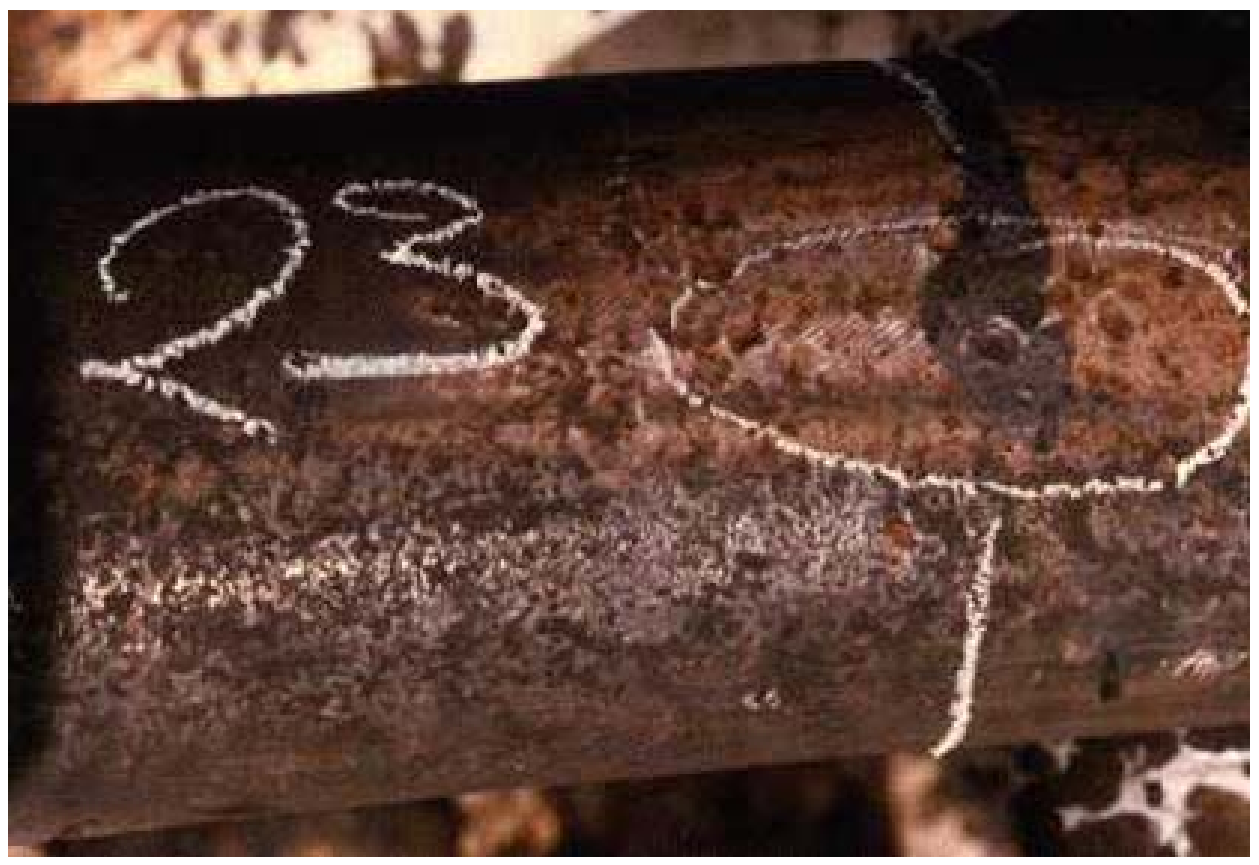

Figure 1. Pitting in a drill pipe. 


\section{Materials and Methods}

\subsection{Gravimetric Test}

The evaluated material in this work was a carbon steel AISI 1020 (0.20\% carbon, $0.34 \%$ $\mathrm{Mn}, 0.35 \% \mathrm{Si}, 0.011 \% \mathrm{~S}$ and $0.009 \% \mathrm{P}$ ) in the confection of the coupons. The coupons used in the gravimetric tests (weight loss) have the following dimensions: $3.17 \mathrm{~cm}$ outside diameter, $0.76 \mathrm{~cm}$ internal diameter and $0.19 \mathrm{~cm}$ thickness. The metal surface was prepared with grade 100 sandpaper until grade 500. They were cleaned with acetone and ethanol and dried with hot air. The test coupons were weighed up to the fourth decimal place using a digital electronic balance.

Gravimetric assays (weight loss) were performed in acrylic containers with a capacity of $20 \mathrm{~L}$ possessing a system of continuous circulation through the injection of compressed air in order to maintain a constant oxygenation rate. To ensure the corrosive medium remained under the same experimental conditions, the solution was continuously filtered where the deposits, precipitates and corrosion products of the coupons were constantly removed, as shown in the diagram in Figure 2.

The solutions used in the experiments were characterized as saline water containing $3.5 \%$ (\% mass) of $\mathrm{NaCl}, 800 \mathrm{mg} / \mathrm{L}$ of $\mathrm{MgCl}_{2}$ and $600 \mathrm{mg} / \mathrm{L}$ of $\mathrm{CaCl}_{2}$. As a corrosion inhibitor, sodium silicate hydrate $\left(\mathrm{Na}_{2} \mathrm{SiO}_{3} \cdot 9 \mathrm{H}_{2} \mathrm{O}\right)$ of high purity at concentrations of 250 , $750,1000,1250,1500,1750$ and $2000 \mathrm{mg} / \mathrm{L}$ was used. The concentrations were referred to as $\mathrm{SiO}_{3}^{2-}$. The exposure time of the coupons was 24,72 and 96 hours of immersion. At the end of each test, the coupons were photographed.

The final mass of each coupon was obtained after the exposure time referenced. Each coupon was washed with water, pickled with Clark solution for 40 seconds according to ASTM G 31 - 72 [3], cleaned with ethanol and dried with hot air.

The difference in weight for an exposed period of 24 - 96 hours was taken as the total weight loss. Four coupons were used to check the reproducibility of the results. From the average weight loss results, the corrosion rate (CR) and the percentage of corrosion inhibition efficiency (\% E) were calculated using equations [3] [4] [5] [6].

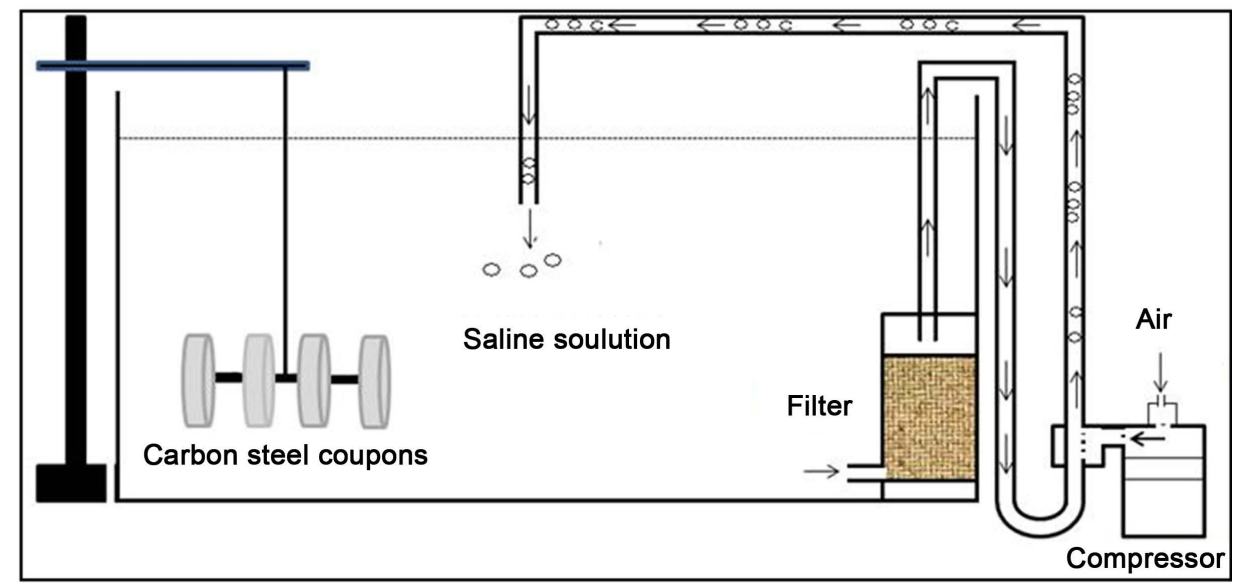

Figure 2. Assay carbon steel immersed in seawater. 


$$
\begin{aligned}
& \text { Corrosion rate }=C R=K\left(W_{o}-W_{i}\right) / \rho \cdot S \cdot t(\mathrm{~mm} / \text { year }) \\
& \text { Inhibition Efficiency }=\% E=\left[\left(W_{o}-W_{i}\right) / W_{o}\right] \times 100
\end{aligned}
$$

where:

$K$ is a constant of $8.76 \times 10^{4}$ (value to $\mathrm{mm} /$ year);

$W_{o}$ and $W_{i}$ are the loss weight in the absence and presence of the inhibitor;

$S=$ area of the coupon $\left(\mathrm{cm}^{2}\right)$;

$\rho=$ density in $\mathrm{g} / \mathrm{cm}^{3}$; carbon steel is $7.8 \mathrm{~g} / \mathrm{cm}^{3}$;

$t=$ exposure time, $\mathrm{h}$.

The degree surface coverage $(\theta)$ of the silicate compound obeys the adsorption law of Langmuir and was calculated using equations [7] [8] [9].

Degree of surface coverage $=\left(C_{\text {inhib }} / \theta\right)=1 / K_{a}+C_{\text {inhib }}$

where:

$C_{\text {inhib }}=$ inhibitor concentration;

$\theta=$ surface coverage $(\theta)$;

$K_{a}=$ equilibrium constant for the adsorption of the inhibitor molecules on the metal surface.

The evaluation of average corrosion rates for carbon steel coupons was based on NACE-RP-07-75 [7], as in Table 1.

\subsection{Electrochemical Tests}

Samples of carbon steel AISI 1020 for the polarization measurements were cut so as to obtain an electrode surface of $0.20 \mathrm{~cm}^{2}$. The metal was then embedded in a polyester resin and polished with No. 600 emery paper. Next, the samples were degreased with acetone and washed in distilled water before being inserted in a conventional polarization cell as shown in Figure 3.

The polarization curves were recorded using an Autolab potentiostat, Type III by varying the potentials $60 \mathrm{mV} / \mathrm{min}$. All measurements were carried out at a constant temperature of $25^{\circ} \mathrm{C}$ under aerated conditions and without agitation.

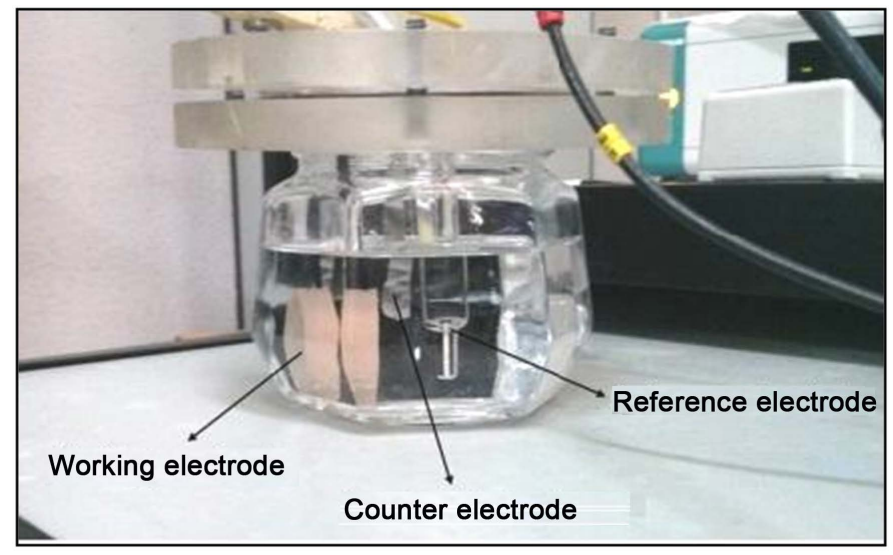

Figure 3. Conventional polarization cell. 
Table 1. Average corrosion rate [7].

\begin{tabular}{cc}
\hline Average corrosion rate, $\mathrm{mm} / \mathrm{y}$ & Corrosiveness \\
\hline$<0.025$ & Low \\
$0.025-0.12$ & Moderate \\
$0.13-0.25$ & High \\
0.25 & Severe \\
\hline
\end{tabular}

\section{Results and Discussion}

The visual appearance (Figure 4) of the carbon steel coupons immersed in the saline solution containing 3.5\% (\% mass) of $\mathrm{NaCl}, 800 \mathrm{mg} / \mathrm{L}$ of $\mathrm{MgCl}_{2}$ and $600 \mathrm{mg} / \mathrm{L}$ of $\mathrm{CaCl}_{2}$ as well as the results of corrosion rates (Table 2) with concentrations of 250 and 1500 $\mathrm{mg} / \mathrm{L}$ of sodium silicate hydrate. The related graphics (Figures 5-7) for exposure times of $24 \mathrm{~h}, 72 \mathrm{~h}$ and $96 \mathrm{~h}$ can be seen in the following.

To understand the mechanism of corrosion inhibition, the adsorption behavior of silicate adsorbents on the metal surface must be known. The predominant adsorption mode will be dependent on factors such as the properties of the composition of the silicate, the dissociation of the silicate in the saline solution, the temperature, possible chemical changes and the nature of the surface charge on the metal.

The values of the surface coverage $(\theta)$, corresponding to different concentrations of silicate in the saline solution, have been used to explain the best isotherm to determine the adsorption isotherm process. The percentage of inhibition efficiency (\% E) and the degree of surface coverage $(\theta)$ were tabulated in Table 3 using a gravimetric assay.

Figure 8 confirms that the inhibition processes are due to the adsorption of the silicate compound by the carbon steel surface. This is because a straight line is obtained when $\left(C_{\text {inhib }} / \theta\right)$ is plotted against $C_{\text {inhib }}$, and the linear correlation coefficient of the fitted data is close to 1 .

The results of the electrolytic tests are presented in Table 4 and in Figure 9.

Based on the graph in Figure 9 the polarization parameters are shown in Table 4, such as: corrosion potential (Ecorr), resistance polarization (Rp) and corrosion current density (Icorr), and the calculated efficiency of sodium silicate in the saline solution. In this figure it is clear the efficiency of addition of sodium silicate on concentration of $1500 \mathrm{mg} / \mathrm{L}$.

It is important to note that, during the gravimetric assays (weight loss), precipitation and the formation of colloidal mixtures of calcium silicates and magnesium hydroxide (considering the high presence of $\mathrm{Ca}^{2+}$ and $\mathrm{Mg}^{2+}$ ions in the saline solution) occurred. This was removed continuously by the filtering system although such precipitation and colloids do not interfere in the corrosion rate results obtained in gravimetric testing. However, the system was a static electrochemical cell and did not have continuous filtration, allowing the formation of precipitates and colloids on the electrodes. In this way, the random occurrence of deposits interfered in electrochemical results as shown in Table 4 and graph (Figure 9). 


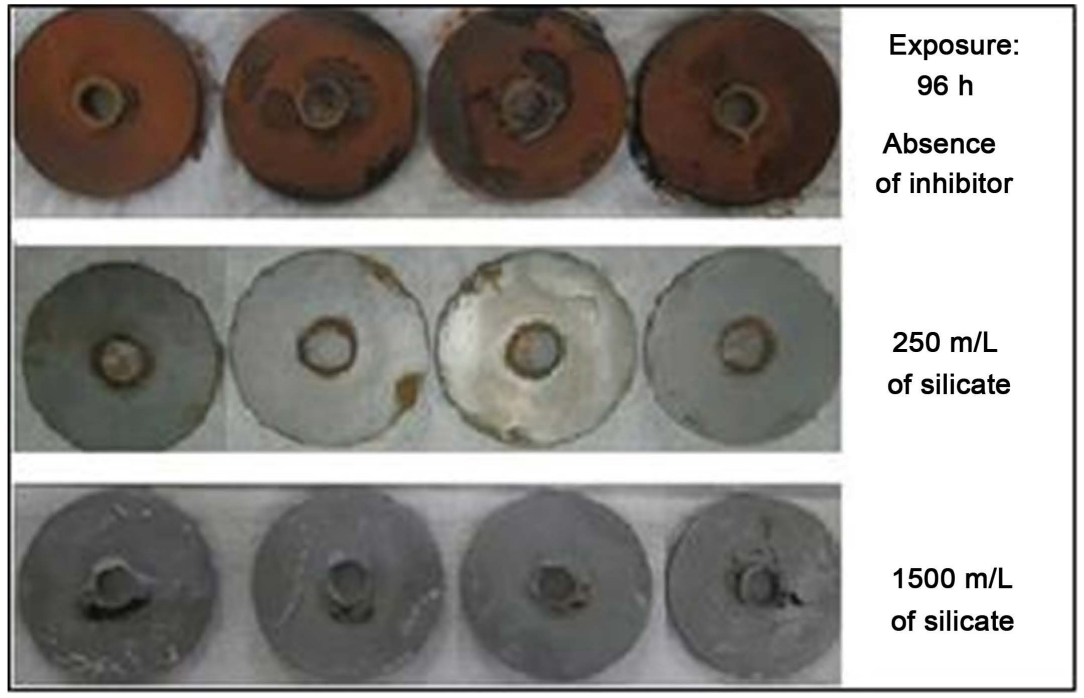

Figure 4. The visual appearance of coupons immersed for $96 \mathrm{~h}$.

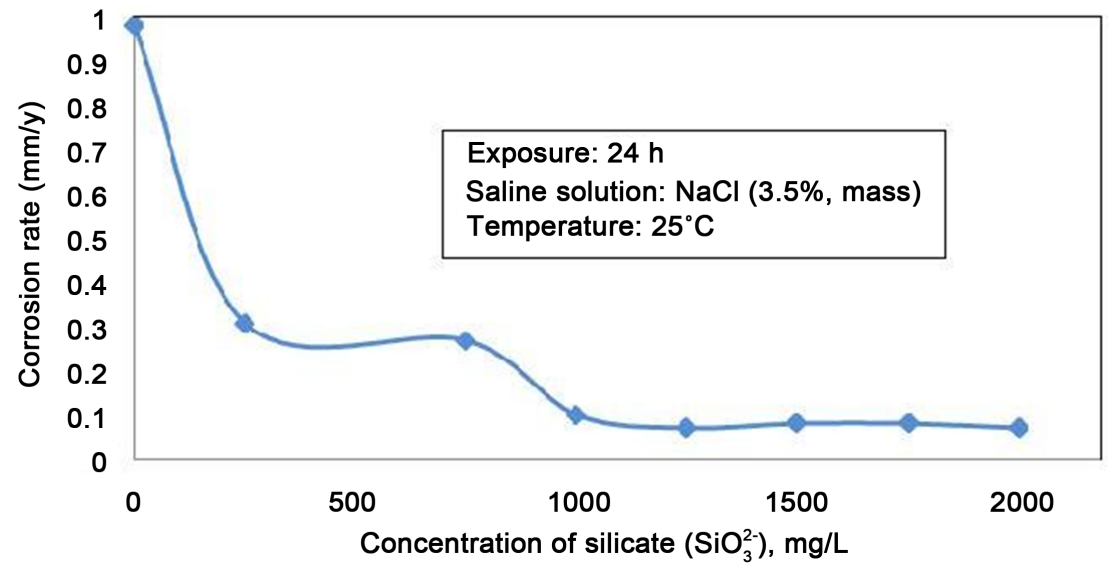

Figure 5. Rate of corrosion of carbon steel coupons in the saline solution with the silicate corrosion inhibitor, $24 \mathrm{~h}$.

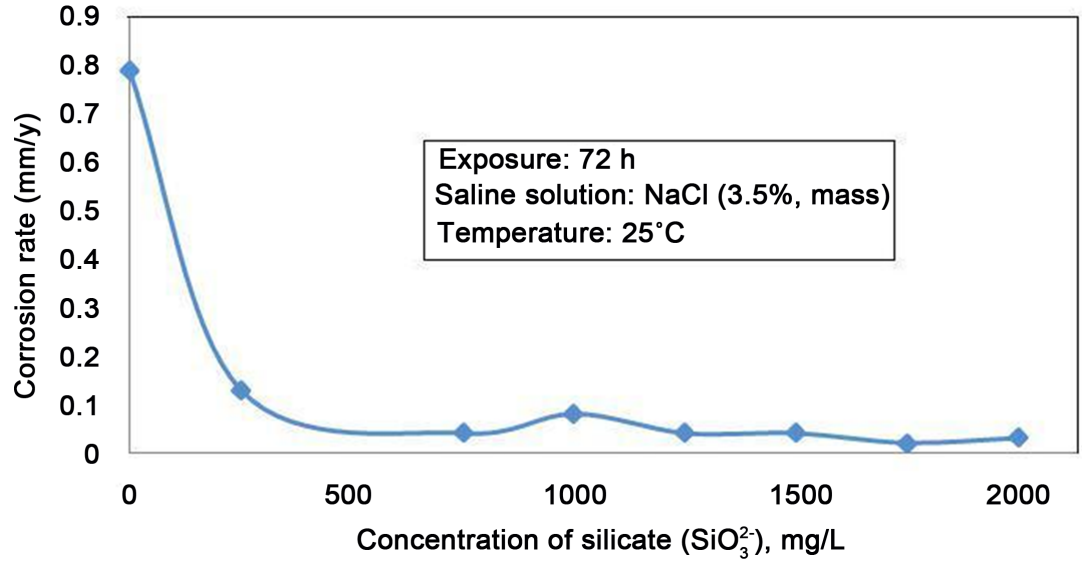

Figure 6. Rate of corrosion of the carbon steel coupon in the saline solution with the silicate corrosion inhibitor, $72 \mathrm{~h}$. 


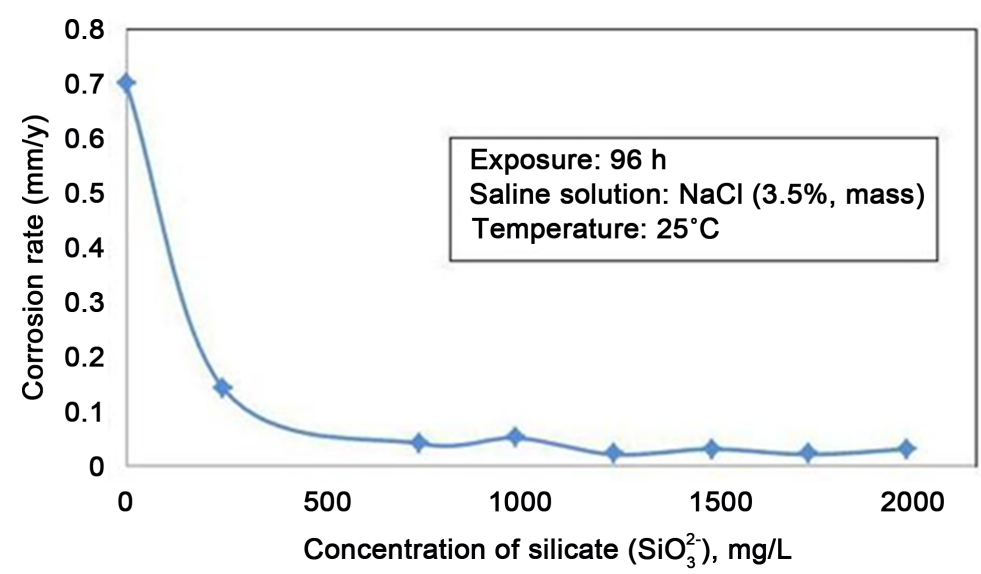

Figure 7. Rate of corrosion of the carbon steel coupon in the saline solution with the silicate corrosion inhibitor, $96 \mathrm{~h}$.

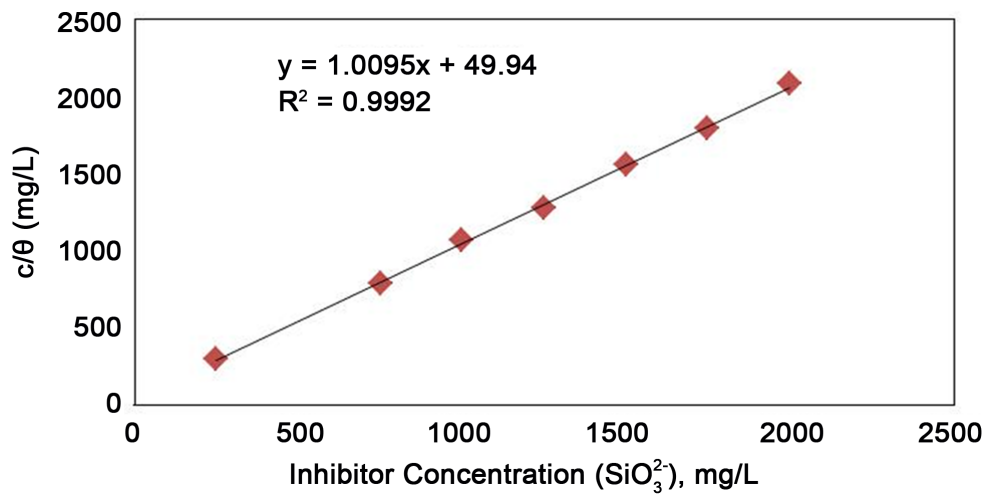

Figure 8. Langmuir adsorption isotherm for the silicate on the carbon steel coupons in the saline solution.

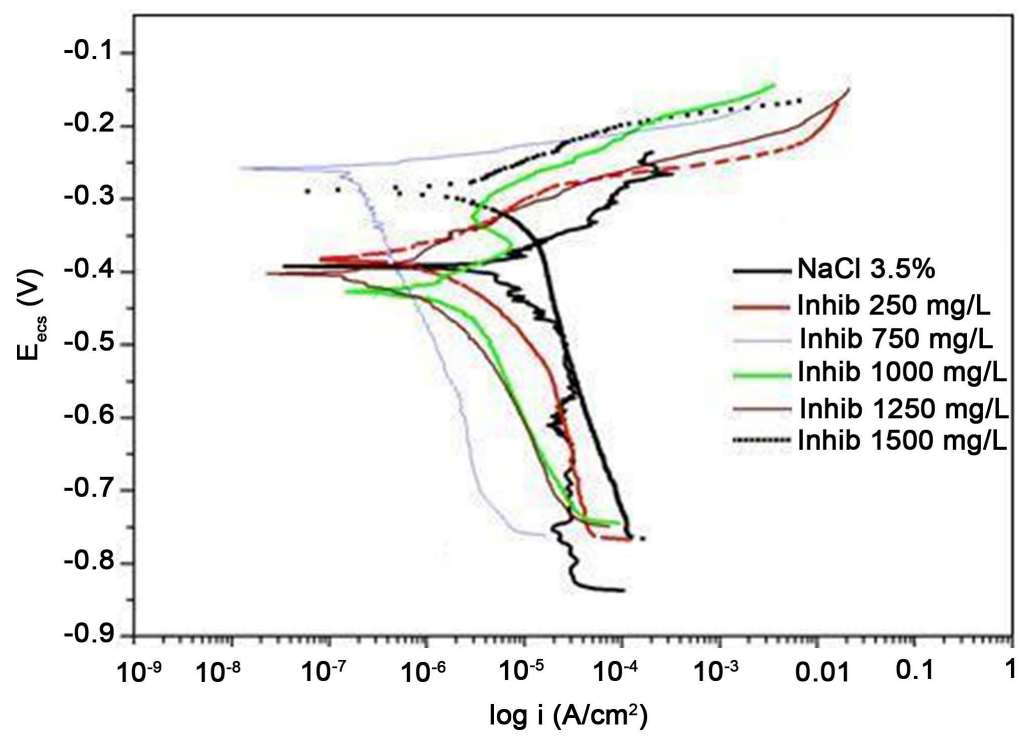

Figure 9. Anodic and cathodic Tafel polarization curves for carbon steel in the absence and presence of various concentrations of the corrosion inhibitor to the base sodium silicate. 
Table 2. Laboratory tests of carbon steel coupons in saline water containing $3.5 \%$ (\% mass) of $\mathrm{NaCl}, 800 \mathrm{mg} / \mathrm{L}$ of $\mathrm{MgCl}_{2}$ and $600 \mathrm{mg} / \mathrm{L}$ of $\mathrm{CaCl}_{2}$.

\begin{tabular}{ccccccc}
\hline \multirow{2}{*}{$\begin{array}{c}\text { Corrosion inhibitor } \\
\text { Silicate }\left(\mathrm{SiO}_{3}^{2-}\right), \mathrm{mg} / \mathrm{L}\end{array}$} & \multicolumn{2}{c}{ Average corrosion rate, $\mathrm{mm} / \mathrm{y}$} & \multicolumn{3}{c}{ Efficiency \% } \\
\cline { 2 - 7 } 0 & $24 \mathrm{~h}$ & $72 \mathrm{~h}$ & $96 \mathrm{~h}$ & $24 \mathrm{~h}$ & $72 \mathrm{~h}$ & $96 \mathrm{~h}$ \\
\hline 250 & 0.99 & 0.79 & 0.70 & - & - & - \\
750 & 0.31 & 0.13 & 0.14 & 68.69 & 83.54 & 80.00 \\
1000 & 0.27 & 0.04 & 0.04 & 72.73 & 94.94 & 94.28 \\
1250 & 0.10 & 0.08 & 0.05 & 89.90 & 89.87 & 92.86 \\
1500 & 0.07 & 0.04 & 0.02 & 92.93 & 94.94 & 97.14 \\
1750 & 0.08 & 0.04 & 0.03 & 91.90 & 94.94 & 95.71 \\
2000 & 0.08 & 0.02 & 0.02 & 91.92 & 97.47 & 97.14 \\
\hline
\end{tabular}

Table 3. Data from gravimetric testing for $96 \mathrm{~h}$.

\begin{tabular}{|c|c|c|c|c|}
\hline Corrosion Inhibitor & $\mathrm{SiO}_{3}^{2-} \quad(\mathrm{mg} / \mathrm{L})$ & Efficiency \% & Surface coverage $(\theta)$ & Concentration $/ \theta(\mathrm{mg} / \mathrm{L})$ \\
\hline 250 & & 80.00 & 0.8000 & 312.50 \\
\hline 750 & & 94.28 & 0.9428 & 795.50 \\
\hline 1000 & & 92.85 & 0.9285 & 1077.00 \\
\hline 1250 & & 97.14 & 0.9714 & 1286.80 \\
\hline 1500 & & 95.71 & 0.9571 & 1567.23 \\
\hline 1750 & & 97.14 & 0.9714 & 1801.52 \\
\hline 2000 & & 95.71 & 0.9571 & 2089.64 \\
\hline
\end{tabular}

Table 4. Electrochemical parameters obtained by the Tafel polarization technique for carbon steel in the absence and presence of various concentrations of silicate $\left(\mathrm{SiO}_{3}^{2-}\right)$.

\begin{tabular}{ccccc}
\hline Conc., $\mathrm{mg} / \mathrm{L}$ & $\mathrm{I}_{\text {corr }}, \mathrm{A}$ & $\mathrm{I}_{\text {corr }}, \mathrm{A} / \mathrm{cm}^{2}$ & $\mathrm{E}_{\text {corr }}, \mathrm{V}$ & $\% \mathrm{E}$ \\
\hline Blank & $3.50 \times 10^{-7}$ & $1.82 \times 10^{-6}$ & -0.393 & - \\
250 & $1.48 \times 10^{-7}$ & $8.30 \times 10^{-6}$ & -0.384 & 54.40 \\
750 & $3.00 \times 10^{-7}$ & $1.55 \times 10^{-6}$ & -0.258 & 91.48 \\
1000 & $1.19 \times 10^{-7}$ & $6.79 \times 10^{-6}$ & -0.427 & 62.70 \\
1250 & $5.56 \times 10^{-7}$ & $3.64 \times 10^{-6}$ & -0.405 & 80.00 \\
1500 & $2.80 \times 10^{-7}$ & $1.46 \times 10^{-6}$ & -0.288 & 19.78 \\
\hline
\end{tabular}

Due to the large amount of deposits and colloids of silicates next to the electrodes, the corrosion rate results and the inhibition efficiency related to $1500 \mathrm{mg} / \mathrm{L}$ of silicate (19.78\%) are not consistent when compared to gravimetric testing.

Many authors referenced have discussed the mechanism of the formation of and the nature of the protective film formed on a metal surface in solutions of sodium silicate. The difference in the proposals of the mechanism of protection and the conclusions 
may be due to the variation in the concentration of the sodium silicate solution, the temperature, the ratio of $\mathrm{Na}_{2} \mathrm{O}$ to $\mathrm{SiO}_{2}$, the experimental conditions, $\mathrm{pH}$, the contamination of certain ions in the saline solution that can form precipitates and colloids and the presence or absence of dissolved oxygen [10] [11] [12] [13] [14]. The proposals of the mechanisms of the formation of the protective film are based on the research of the authors previously referenced and presented as models in Figure 10 and Figure 11.

Sodium silicate has a strong anodic inhibition in a highly alkaline medium, providing that the $\mathrm{SiO}_{3}^{2-}$ ions migrate to the anode region of the metal surface and react with $\mathrm{Fe}^{2+}$ ions, thus forming a protective film of iron silicate $\left(\mathrm{FeSiO}_{3}\right)$, as can be seen in Figure 10.

The $\mathrm{Mg}^{2+}$ and $\mathrm{Ca}^{2+}$ ions present in the saline solution may migrate to the cathodic area, find the $\mathrm{OH}^{-}$ions and form a protective film of $\mathrm{Mg}(\mathrm{OH})_{2}$ and $\mathrm{Ca}(\mathrm{OH})_{2}$. Over time, it is possible to obtain a uniform protective film on the metal surface by adsorption, in an alkaline medium, by inhibiting anodic and cathodic reactions, providing an excellent carbon steel protection against corrosion in a saline solution. This film is made up of iron silicate $\left(\mathrm{FeSiO}_{3}\right)$, calcium silicate $\left(\mathrm{CaSiO}_{3}\right)$, magnesium silicate $\left(\mathrm{MgSiO}_{3}\right)$ and silica $\left(\mathrm{SiO}_{2}\right)$, these being associated with calcium hydroxide and magnesium hydroxide, as shown in Figure 10.

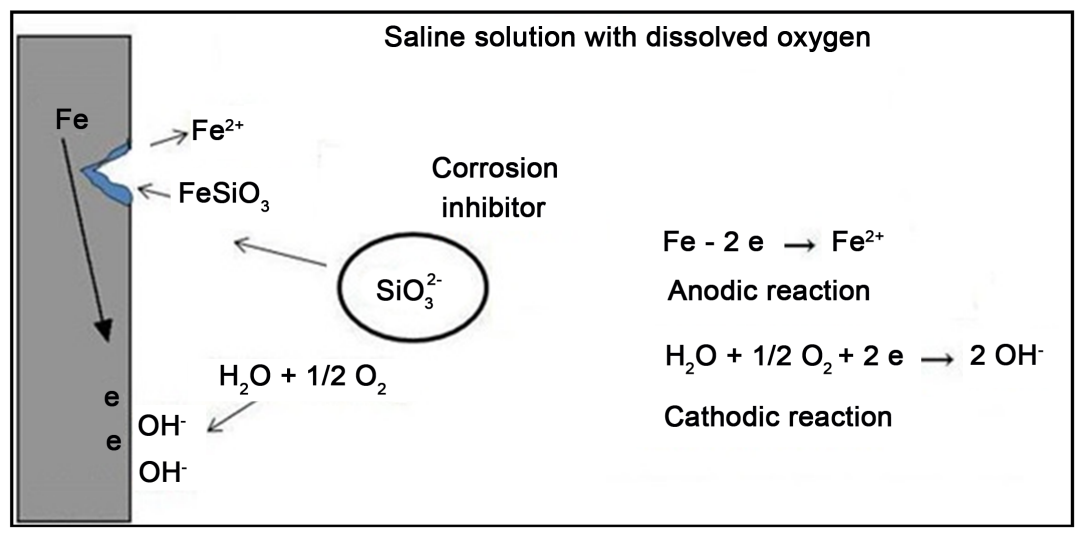

Figure 10. Silicate formation on a metal surface in a saline solution with dissolved oxygen.

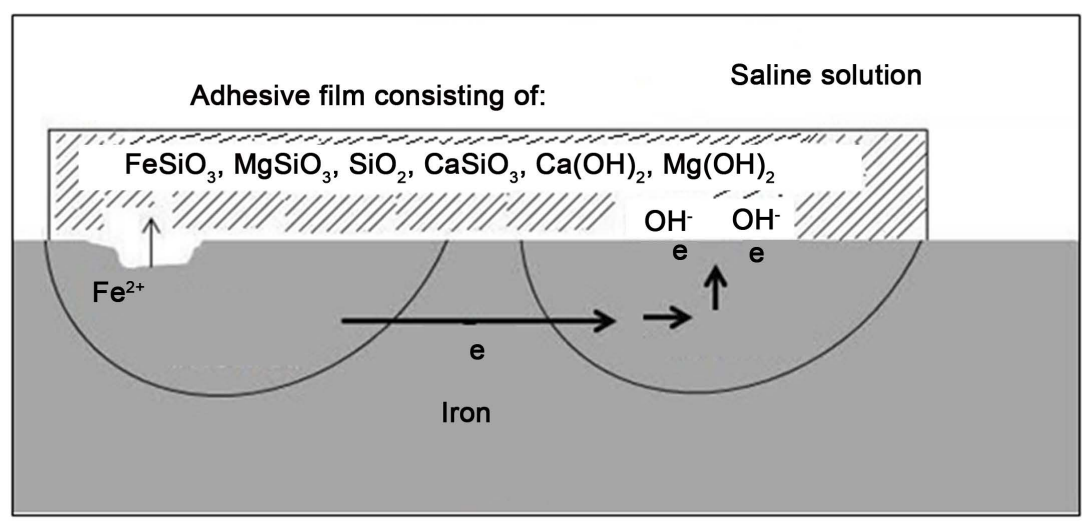

Figure 11. Proposed barrier mechanisms to silicate in the saline solution. 


\section{Conclusions}

On the basis of the bibliographic references and laboratory tests carried out, it is concluded that:

- Through gravimetric testing of the addition of sodium silicate in different concentrations, the formation of a protective film on the surface of the carbon steel, which provided a drastic reduction in the corrosion rate, according to the increase of the concentration of the inhibitor and the immersion time, was observed;

- The concentration of inhibitor that showed better performance was $1250 \mathrm{mg} / \mathrm{L}$, with values of corrosion rates of $0.07 \mathrm{~mm} /$ year, $0.04 \mathrm{~mm} /$ year, $0.02 \mathrm{~mm} /$ year and 0.03 $\mathrm{mm} /$ year and $92.93 \%, 94.94 \%, 97.14 \%$ and $94.00 \%$ efficiency for immersion times of 24, 72, 96 and 120 hours respectively;

- For the addition of sodium silicate above $1250 \mathrm{mg} / \mathrm{L}$, significant changes in the rate of corrosion were not observed;

- The electrochemical tests were not conclusive, compared to gravimetric testing, due to the presence of $\mathrm{Ca}^{2+}$ and $\mathrm{Mg}^{2+}$ ions in the saline that propitiated the formation of precipitates and colloids (calcium silicate, magnesium silicate, calcium hydroxide and magnesium hydroxide) on the electrodes. This disrupted the transmission of the electrochemical parameters;

- The adsorption capacity of the sodium silicate on the carbon steel is based on the Langmuir isotherm;

- The mechanism proposed for the corrosion protection of carbon steel is based on the formation of a uniform and transparent film with a gelatinous aspect on the steel surface constituted of iron silicate, calcium silicate, magnesium silicate and silica, these being associated with calcium hydroxide and magnesium hydroxide;

- Considering the good results of carbon steel corrosion protection obtained with the addition of sodium silicate in a saline fluid, application in the drilling fluids of oil wells, especially for salt water-based fluids, is possible since these fluids present many products that are toxic, corrosive and harmful to the environment.

\section{References}

[1] Fink, J.K. (2003) Oil Fields Chemicals. Gulf Professional Publishing, New York.

[2] Macdonald, K.A. and Bjune, J.V. (2007) Failure Analysis of Drill Strings. Engineering Failure Analysis, 14, 1641-1666. https://doi.org/10.1016/j.engfailanal.2006.11.073

[3] (1999) ASTM G31-72, Standard Practice for Laboratory Immersion Corrosion Testing of Metals.

[4] Baboian, R. (2005) Corrosion Tests and Standards: Application and Interpretation. Vol. 20, ASTM International, Pennsylvania. https://doi.org/10.1520/MNL20-2ND-EB

[5] Revie, R.W. and Uhlig, H.H. (2011) Uhlig's Corrosion Handbook. John Wiley \& Sons, Hoboken. https://doi.org/10.1002/9780470872864

[6] Roberge, P.R. (2000) Handbook of Corrosion Engineering. Vol. 1128, McGraw-Hill, New York.

[7] (2005) NACE-RP0775, Standard Recommended Practice: Preparation, Installation, Analy- 
sis, and Interpretation of Corrosion Coupons in Oilfield Operations. NACE International.

[8] El-Etre, A.Y. and Abdallah, M. (2000) Natural Honey as Corrosion Inhibitor for Metals and Alloys. II. C-Steel in High Saline Water. Corrosion Science, 42, 731-738.

https://doi.org/10.1016/S0010-938X(99)00106-7

[9] Felipe, M.B.M.C., Silva, D.R., Martinez-Huitle, C.A., Medeiros, S.R.B. and Maciel, M.A.M. (2013) Effectiveness of Croton cajucara Benth on Corrosion Inhibition of Carbon Steel in Saline Medium. Materials and Corrosion, 64, 530-534.

https://doi.org/10.1002/maco.201206532

[10] Mohammedi, D., Benmoussa, A., Fiaud, C. and Sutter, E.M.M. (2004) Synergistic or Additive Corrosion Inhibition of Mild Steel by a Mixture of HEDP and Metasilicate at $\mathrm{pH} 7$ and 11. Materials and Corrosion, 55, 837-844. https://doi.org/10.1002/maco.200403794

[11] Armstrong, R.D. and Zhou, S. (1988) The Corrosion Inhibition of Iron by Silicate Related Materials. Corrosion Science, 28, 1177-1181.

https://doi.org/10.1016/0010-938X(88)90126-6

[12] White, R.T. and Malherbe, J.B. (1986) An Auger Electron Spectroscopic Investigation on Mild Steel Corrosion in Silicate Treated Water. Applied Surface Science, 25, 32-40. https://doi.org/10.1016/0169-4332(86)90023-1

[13] Lahodny-Šarc, O. and Kaštelan, L. (1981) The Influence of pH on the Inhibition of Corrosion of Iron and Mild Steel by Sodium Silicate. Corrosion Science, 21, 265-271. https://doi.org/10.1016/0010-938X(81)90002-0

[14] Yuan, M.R., Lu, J.T., Kong, G. and Che, C.S. (2011) Effect of Silicate Anion Distribution in Sodium Silicate Solution on Silicate Conversion Coatings of Hot-Dip Galvanized Steels. Surface \& Coatings Technology, 205, 4466-4470.

https://doi.org/10.1016/j.surfcoat.2011.03.064

\section{Submit or recommend next manuscript to SCIRP and we will provide best service} for you:

Accepting pre-submission inquiries through Email, Facebook, LinkedIn, Twitter, etc.

A wide selection of journals (inclusive of 9 subjects, more than 200 journals)

Providing 24-hour high-quality service

User-friendly online submission system

Fair and swift peer-review system

Efficient typesetting and proofreading procedure

Display of the result of downloads and visits, as well as the number of cited articles

Maximum dissemination of your research work

Submit your manuscript at: http://papersubmission.scirp.org/

Or contact jep@scirp.org 